\title{
Religie op het werk?
}

\section{Over positieve en negatieve godsdienstvrijheid bij private ondernemingen en tendensondernemingen}

\author{
Leni Franken \& François Levrau
}

\section{Inleiding}

De vraag wat de plaats van religie op de werkvloer is, wordt niet zelden beperkt tot een (publieke, politieke en academische) discussie over de mate waarin een overheid nog wel neutraal is wanneer er wordt toegestaan dat ambtenaren met levensbeschouwelijke en andere symbolen verschijnen. ${ }^{1}$ Nochtans hoeft die vraag allerminst tot deze specifieke casus te worden beperkt, omdat ook private ondernemingen en tendensondernemingen (ondernemingen, organisaties of verenigingen die zijn gegrondvest op een bepaald geloof of op een bepaalde levensbeschouwing) zich geconfronteerd weten met de vraag of (en in welke mate) het mogelijk is om gevolg te geven aan bepaalde levensbeschouwelijke overtuigingen. Omdat die context van de private en tendensondernemingen wat minder aandacht lijkt te krijgen, wil deze bijdrage aan dit hiaat tegemoetkomen en aan de slag gaan met een aantal concrete en prangende kwesties. Hoe dient een werkgever bijvoorbeeld om te gaan met werknemers die op vrijdag naar de gebedsdienst willen gaan of die zaterdag willen rusten? Wat moet hij/zij doen wanneer een werknemer geen alcoholische dranken wil serveren op een receptie? Hoe moet hij/zij reageren wanneer een personeelslid weigert diensten te verlenen aan holebi's of weigert iemand van het andere geslacht de hand te schudden? Moet hij/zij meegaan met de vraag van werknemers die religieuze symbolen willen dragen of kan en mag hij/zij hen vragen die symbolen thuis te laten? Deze en soortgelijke kwesties peilen naar de mate waarin de werkgever eraan gehouden is religieuze claims op de werkvloer te accommoderen.

1 François Levrauen Patrick Loobuyck, 'With or Without Religious Symbols? Why Political Liberalism is Inconclusive in the Case of Civil Servants', Res Publica: A Journal of Legal and Social Philosophy (2020). doi.org/10.1007/s11158-019-09446-z. 
Dat dit geen eenvoudige en eenduidige materie is, blijkt onder meer uit het feit dat de Europese gerechtshoven (EHRM en HvJ-EU) ${ }^{2}$ er zich in het verleden al geregeld over hebben moeten uitspreken. Deze gerechtshoven behandelden overigens niet enkel casussen die te maken hebben met de manifestatie van religieuze symbolen van werknemers (positieve godsdienstvrijheid), maar ook casussen die betrekking hebben op de vraag in hoeverre werknemers in tendensondernemingen beschermd kunnen en mogen worden tegen de religieuze eisen van hun werknemer (negatieve godsdienstvrijheid). Is het bijvoorbeeld toegelaten dat een leerkracht rooms-katholieke godsdienst openlijk kritiek uit op de katholieke kerk? Mag een christelijke school leerkrachten weigeren omdat ze niet gedoopt zijn? En wat moet er gebeuren wanneer de echtelijke status van de werknemer niet in overeenstemming is met het religieuze ethos van de werkgever?

Deze en soortgelijke kwesties lenen zich bij uitstek tot rechtsfilosofische analyses. In dit artikel verlaten we ons dan ook op de combinatie van (politieke) filosofie en rechtsleer. We starten met een uiteenzetting van twee contrasterende visies die we binnen de hedendaagse politiek-filosofische theorievorming terugvinden: enerzijds de difference-blind benadering die onder meer door Brian Barry (1936-2009) op invloedrijke wijze werd verdedigd, en anderzijds de difference-sensitive benadering die we onder meer terugvinden bij Bhikhu Parekh (1935). Na een schets van deze theoretische posities bekijken we het principe van redelijke accommodatie. Wat houdt dit precies in en op welke manier wordt het toegepast op de werkvloer in Europa? Biedt het als concept en instrument enig soelaas in de beantwoording van de vraag of er ruimte kan zijn voor religie op de werkvloer? In de drie daarop volgende secties gaan we concreet in op een aantal juridische casussen van het EHRM en het HvJ-EU. Hoewel beide Europese gerechtshoven andere bevoegdheden en afdwingingsmechanismen hebben, menen we dat het zinvol is om - gegeven het onderwerp van deze bijdrage - de rechtspraak van de beide gerechtshoven te bekijken. Immers, zowel het EHRM als het HvJ-EU hebben reeds uitspraken gedaan over de accommodatie van religieuze/levensbeschouwelijke symbolen op de werkvloer en het is dan ook, vanuit normatief en rechtsvergelijkend perspectief, een interessante oefening om de argumentatie die

2 Het Europees Hof voor de Rechten van de Mens (EHRM) ziet er op toe dat Europese lidstaten de rechten en plichten, zoals vastgelegd in het Europees Verdrag voor de Bescherming van de Rechten van de Mens (EVRM), naleven. Indien dit niet het geval is, kunnen individuen, groepen, organisaties en landen een klacht indienen tegen een lidstaat, die dan door het EHRM wordt behandeld. Anders dan het Hof van Justitie van de EU (HvJ-EU) is het EHRM geen instelling van de Europese Unie, maar van de Raad van Europa, waar bijna 50 landen bij zijn aangesloten. De uitspraken van het Hof zijn definitief en bindend voor de betrokken staten. Het Hof van Justitie van de Europe Unie ziet er dan weer op toe dat de EU-wetgeving in alle landen van de EU op dezelfde wijze wordt geïnterpreteerd en toegepast en regelt juridische geschillen tussen nationale regeringen en EU-instellingen. In bepaalde omstandigheden kunnen ook particulieren, bedrijven en organisaties zaken bij dit Hof aankaarten, met name als zij van mening zijn dat hun rechten door een EU-instelling zijn geschonden. Een voor deze bijdrage belangrijk verschil tussen beide instellingen is dat de uitspraken van het HvJ-EU bindend zijn in al haar facetten voor de EU-lidstaten, terwijl het EHRM een ruime appreciatiemarge (margin of appreciation) toekent aan de lidstaten. Hierdoor kan het EHRM expliciet rekening houden met de socioculturele, historische (en ook religieuze) verschillen tussen de lidstaten. 
in de betreffende gerechtshoven wordt gebruikt van naderbij te bekijken. We bespreken achtereenvolgens (1) neutrale ondernemingen, (2) private ondernemingen en (3) tendensondernemingen. Na deze casuïstiek zetten we de discussie verder op scherp en formuleren we een aantal bedenkingen die aantonen waarom vragen omtrent de accommodatie van religie op de werkvloer moeilijk eenduidig kunnen worden beantwoord. We illustreren concreet de mate waarin discussies omtrent religie in de werksfeer worden bemoeilijkt door de onduidelijkheid van een aantal frequent gebruikte concepten en verwijzen uiteindelijk naar het belang van contextualiteit en proportionaliteit.

\section{Een difference-blind benadering}

De 17e-eeuwse filosoof John Locke (1632-1704) is een van de eerste rechtsfilosofen die expliciet ingaat op religieuze tolerantie en de scheiding tussen kerk en staat. Zo stelt hij in zijn Brief over Tolerantie (1689) dat de kerkelijke en burgerlijke overheden zich niet met elkaar moeten moeien omdat ze beiden verschillende taken hebben: terwijl de burgerlijke overheid zich inlaat met het wereldlijke heil, richt de kerk zich op het zielenheil. ${ }^{3}$ Verder stelt Locke ${ }^{4}$ dat handelingen die toegelaten zijn in een seculiere context (bv. baby's wassen met water; wijn drinken en brood eten) ook toegelaten zijn in een religieuze context (doopsel; eucharistie). Wanneer er goede argumenten voorhanden zijn om bepaalde handelingen niet toe te laten in een seculiere context, dan gelden deze argumenten eveneens in een religieuze context. Belangrijk hierbij is dat deze handelingen niet verboden worden omwille van hun religieuze karakter, maar omdat er dus algemene en neutrale argumenten zijn voor een dergelijke regelgeving. ${ }^{5}$ Kortom, de burgerlijke wetgeving begrenst wat al dan niet is toegelaten in een religieuze context.

Op het eerste zicht lijkt Locke's positie erg aannemelijk: door gelovigen en nietgelovigen gelijk te behandelen en gelijke rechten te geven, wordt er niemand gediscrimineerd en is de overheid neutraal. Maar is de formeel gelijke behandeling inderdaad altijd en overal de beste manier voor een overheid die haar burgers op voet van gelijkheid wil behandelen? Moet er niet ook rekening gehouden worden met het feit dat mensen van nature verschillend zijn en moeten ze daarom niet zozeer 'gelijk' behandeld worden, maar wel 'als gelijken'? Het egalitair-liberalisme (met John Rawls en Ronald Dworkin als pioniers) heeft die visie ter harte genomen. Wanneer de overheid een difference-blind beleid voert en dus iedereen op dezelfde manier behandelt zonder rekening te houden met verschillen tussen burgers, dan worden sommige burgers bevoorrecht en anderen benadeeld. Een overheid houdt daarom best rekening met de 'ongekozen omstandigheden' waardoor mensen benadeeld kunnen zijn en zij moet die benadeling vervolgens compenseren door

3 Locke John, A letter concerning tolerance (London: Broadview Press, 2013 [1689]), 70.

4 Locke, A letter concerning tolerance, 70.

5 Locke, A letter concerning tolerance, 70. 
de implementatie van een goed uitgebouwd sociaaleconomisch beleid. ${ }^{6}$ Een egalitair-liberale overheid moet dus bijvoorbeeld bijzondere voorzieningen treffen voor mensen met een fysieke beperking of zij moet sociaaleconomische bijstand verlenen aan mensen die door omstandigheden (brute luck) slechter af zijn. Alleen zo kan worden gegarandeerd dat elk individu werkelijk gelijke kansen (equal opportunities) heeft om het leven in vrijheid vorm te geven.

Het egalitair-liberalisme laat echter niet toe dat er bijvoorbeeld uitzonderings- of compensatieregels worden gemaakt voor mensen die een dure smaak hebben. ${ }^{7}$ Wie graag oesters eet en champagne drinkt, moet de gevolgen van zijn/haar expensive preferences dragen en meer betalen dan wie tevreden is met water en brood. De redenering hier is dat een smaak of preferentie kan worden veranderd of dat men er althans niet noodzakelijk moet aan tegemoet komen, in tegenstelling tot een fysieke beperking waaraan men strikt gebonden is. Zo kan iemand die graag oesters eet en champagne drinkt in principe ook gewoon op water en brood leven, ook al zou men dit liever niet doen. Voor een fysieke beperking staan de zaken er anders voor: in vele gevallen is deze onomkeerbaar en onveranderlijk. Gezien het volgens Rawls en Dworkin niet gaat om het gelijkstellen van de mate van welzijn (satisfaction of welfare), maar wel om het egaliseren van basismiddelen (resources) die elk mens nodig heeft om een leven in vrijheid vorm te geven, moet de hedonist niet worden gecompenseerd wanneer hij merkt dat hij, na verloop van tijd, blut is. ${ }^{8}$ Van mensen mag en moet immers worden verwacht dat ze de gevolgen van hun keuzes en smaken dragen. Echter, om diezelfde gelijkheid van kansen te garanderen, is het wel rechtvaardig om als overheid te voorzien in allerhande tegemoetkomingen voor mensen met een fysieke beperking. In de realiteit betekent dit dat mensen met en zonder fysieke beperking niet gelijk, maar verschillend worden behandeld: denk maar aan apart sanitair, aparte ingangen in gebouwen, aparte parkeerplaatsen, etc., die uitsluitend bedoeld zijn voor mensen met een fysieke beperking. Kortom, mensen als gelijken behandelen betekent niet noodzakelijk dat ze formeel gelijk behandeld worden.

Een belangrijke vraag is of religie en/of cultuur behoren tot de categorie van ongekozen omstandigheden, dan wel tot de categorie van dure smaken. Moet de overheid met andere woorden zorgen voor de nodige accommodatie van religie en cultuur, zodat mensen met uiteenlopende levensbeschouwelijke en culturele achtergronden en overtuigingen gelijke kansen hebben? Of moet de overheid hier een handsoff beleid voeren (en dus niets extra doen) en religie/cultuur behandelen als expensive preferences?

6 Dworkin, Ronald, Sovereign virtue. The theory and practice of equality (Cambridge: Harvard University Press, 2000).

7 Dworkin, Sovereign virtue, 80ff. Rawls, John, 'Fairness to Goodness', Philosophical Review 84/4 (1975): 536-554. Rawls, 'Social Unity and Primary Goods', in Utilitarianism and Beyond, red. Amartya Sen en Bernard Williams (Cambridge: Cambridge University Press, 1982), 159-186.

8 We gaan hier even voorbij aan de vele nuances die binnen het brede debat over 'luck egalitarianism' kunnen worden gemaakt, zie bijvoorbeeld Lippert-Rasmussen Kasper, Luck egalitarianism (London: Bloomsbury, 2016). 
De Britse filosoof Brian Barry verdedigt alvast deze laatste positie in zijn boek Culture \& Equality ${ }^{9}$ dat algemeen wordt beschouwd als de scherpste en, vanuit academisch oogpunt beschouwd, meest invloedrijke aanval op het multiculturalisme. ${ }^{10}$ Volgens hem zijn bijzondere voorzieningen niet legitiem als ze dienen om culturele en religieuze 'voorkeuren' te compenseren of te accommoderen. Het feit dat religieuze en/of culturele preferenties (bv. halal eten; een hoofddoek, keppel of tulband dragen; geen alcohol willen serveren omwille van religieuze overtuiging) vaak niet zomaar gekozen zijn, maar eerder het gevolg zijn van sociale inbedding (embeddedness) doet daar geen afbreuk aan. Een jood of moslim die geen varkensvlees eet omwille van religieuze redenen verschilt op dit punt fundamenteel van iemand die geen varkensvlees eet omwille van allergische redenen: terwijl er voor de persoon met allergie geen andere keuze is, kan de jood of moslim in principe wel kiezen om varkensvlees te eten. Joden en moslims worden bovendien ook niet verplicht om vlees te eten; er wordt alleen vanuit hun religie verwacht dat ze geen varkensvlees eten. Bijgevolg moet de overheid volgens Barry niet voorzien in uitzonderingsregels met betrekking tot religie. Volgens Barry zijn mensen immers steeds zelf verantwoordelijk voor wat ze met hun (levensbeschouwelijke en culturele) opvattingen, preferenties en keuzes doen.

Barry maakt dus, net zoals Dworkin, een fundamenteel onderscheid tussen iemands keuzemogelijkheden enerzijds, en de individuele invulling van die mogelijkheden anderzijds: terwijl individuele burgers zelf verantwoordelijk zijn voor de manier waarop ze met de hen aangeboden kansen en mogelijkheden omgaan, komt het aan de overheid toe om die kansen en mogelijkheden voor iedereen zo fair mogelijk te verdelen. Rechtvaardige wetten en regels moeten bijgevolg zo worden opgesteld dat ze zoveel mogelijk gelijke kansen voor iedereen garanderen. Als blijkt dat er geen gelijke kansen worden gegenereerd, is de betreffende wet volgens Barry geen rechtvaardige wet:

With almost no exceptions, either there is a good enough case for having a law to foreclose exemptions or alternatively the case for having a law is not strong enough to justify its existence at all. ${ }^{11}$

Indien een wet toch niet zou leiden tot gelijke kansen, moet de betreffende wet niet worden aangevuld met allerlei mogelijke uitzonderingen (de rule and exemption-benadering), want dat zou alleen maar leiden tot meer ongelijkheid. Beter is het om de algemene wetgeving aan te passen, zodat er zoveel mogelijk gelijke kansen voor iedereen gegarandeerd zijn. Dit geldt ook voor religieuze praktijken: ofwel is de wetgeving voldoende gefundeerd om bepaalde praktijken te verbieden en zijn uitzonderingsregels overbodig, ofwel is de vraag voor een uitzondering voldoende gefundeerd om de algemene wet aan te passen. ${ }^{12}$ versity Press, 2001).

10 Kelly, Paul (red.). Multiculturalism reconsidered (Cambridge: Polity Press, 2002).

11 Barry, Culture and equality, 321.

12 Barry, Culture and equality, 39ff. 
Een voorbeeld kan dit verduidelijken. Volgens de Vlaamse wetgeving was het tot 2004 niet toegelaten om mensen zonder kist te begraven of te cremeren. Voor moslims was dit echter een probleem: de islam schrijft immers voor dat overledenen in een doek gewikkeld worden (en dus niet in een kist worden gelegd) voor ze begraven worden. Om hieraan tegemoet te kunnen komen heeft de Vlaamse overheid haar regelgeving omtrent begrafenissen aangepast: sinds het Decreet op de begraafplaatsen en de lijkbezorging van 2004 is het ook mogelijk om iemand zonder kist te begraven (art. 11). De enige (neutrale) voorwaarde is dat de overledenen begraven moeten worden op een wijze die in lijn is met de volksgezondheid (en dat hoeft dus niet per se met behulp van een kist). Door de aanpassing van deze wet is het nu voor moslims mogelijk om hun overledenen conform de eigen culturele/religieuze traditie te begraven, zonder dat hiervoor (multiculturele) uitzonderingsrechten moeten worden voorzien. Maar ook niet-moslims kunnen er sinds 2004 in Vlaanderen voor kiezen om nabestaanden zonder kist te laten begraven een optie die het overwegen waard is gezien het hoge prijskaartje van een kist.

\section{Een difference-sensitive benadering}

Tegenover de difference-blind benadering van Barry staat de difference-sensitive benadering, die onder meer wordt verdedigd door de Britse filosoof en politiek denker Bhikhu Parekh. Wat hij beklemtoont is dat iemands religieuze en culturele identiteit niet zomaar wordt 'gekozen', maar eerder het gevolg is van een ongekozen religieuze of culturele inbedding (embeddedness). Omdat mensen onherroepelijk verbonden zijn met en gevormd worden door hun religieuze en culturele achtergrond die ze, net zoals een fysieke beperking, niet zomaar van zich kunnen afschudden (althans niet zonder de kost van een diepe psychische desoriëntatie), moet de overheid religieuze en culturele praktijken accommoderen. Alleen op die manier worden alle burgers (wat hun culturele of religieuze affiliatie ook moge zijn) daadwerkelijk gerespecteerd en dus als moreel gelijkwaardig behandeld. Uniforme wetgeving, zoals Barry voorstelt, is dus volgens Parekh geen oplossing:

Equal rights do not mean identical rights, for individuals with different cultural backgrounds and needs might require different rights to enjoy equality in respect of whatever happens to be the content of their rights. Equality involves not just rejection of irrelevant differences as is commonly argued, but also full recognition of legitimate and relevant ones. ${ }^{13}$

Wanneer blijkt dat algemene wetten ontoereikend zijn om culturele en religieuze vrijheden van minderheden de facto te garanderen, moet de overheid uitzonderingen toelaten. Enkel in dat geval zijn gelijke kansen daadwerkelijk voor iedereen gegarandeerd. Een gekend voorbeeld van een dergelijke uitzonderingsregel is het amendement op de American Indian Religious Freedom Act (Public Law No 103-344, 
6 oktober 1994), die het sacramenteel gebruik van de hallucinogene peyote plant in traditionele religieuze ceremonies toelaat. Een ander voorbeeld zijn uitzonderingsregels op de wegcode in onder meer Groot-Brittannië, Maleisië en een aantal Canadese provincies, waar sikhs die een tulband dragen geen helm hoeven op te zetten wanneer ze zich met de motorfiets verplaatsen.

Zoals gesteld is Barry nogal terughoudend ten aanzien van uitzonderingsregels. Uitzonderingen kunnen er immers toe leiden dat sommige burgers voorrechten verkrijgen. Waarom mag bijvoorbeeld een sikh zonder helm rijden, terwijl een motorrijder die puur voor het plezier zonder helm wil rijden dat niet mag? Waarom mag men enkel binnen een bepaalde religieuze context verdovende middelen gebruiken, terwijl het gebruik van diezelfde middelen buiten die context strafbaar is? Leidt dit soort wetgeving (rule and exemption) niet onherroepelijk tot meer in plaats van minder ongelijkheid?

Ondanks Barry's bekommernis laat hij in bepaalde gevallen toch uitzonderingen op algemene regels toe om daadwerkelijk gelijke kansen voor iedereen te garanderen. Anders dan 'multiculturalisten' zoals Parekh beschouwt Barry deze uitzonderingen echter niet als rechten, maar als pragmatische oplossingen: indien een groep mensen door bepaalde rechten of plichten geschaad wordt en daardoor niet (meer) kan functioneren in de maatschappij, zijn uitzonderingsregels tijdelijk toegestaan, 'for as long as the inequality persists'. ${ }^{14}$ Zo is iedereen op een bouwwerf volgens de Britse wetgeving verplicht om een helm te dragen, maar omdat er erg veel sikhs actief zijn in de bouwsector, zou het (voor de sikhs) contraproductief zijn om het dragen van een helm ook voor hen verplicht te maken en dus het dragen van een tulband onmogelijk te maken. Sikhs zouden dan moeten kiezen tussen hun levensbeschouwing en hun werk - en allicht veelal voor het eerste kiezen, met de nodige sociale gevolgen. Daarom - i.e. om pragmatische redenen (en omdat een tulband uiteindelijk ook een zekere bescherming biedt) - is een uitzonderingsregel als tijdelijke oplossing toegestaan. Opvallend is dat Barry's pragmatisch denken uiteindelijk tot heel wat multiculturele maatregels leidt.

Parekh and I are not so far apart as might be supposed on political issues in Britain. I would be surprised if, out of a hundred controverted questions, we would disagree on more than one or two. Where we differ is the way we get there. ${ }^{15}$

Wanneer we de nuances laten voor wat ze zijn, zijn zowel Barry als Parekh het er bijvoorbeeld over eens dat (1) Amerikaanse indianenstammen peyote mogen gebruiken in een rituele context, ook al gaat dit in tegen het regionale drugsbeleid; (2) sikhs een tulband mogen dragen op scholen waar een uniform (zonder hoofddeksel) wordt gedragen; (3) sikhs een tulband in plaats van een helm mogen dragen op de bouwwerf; (4) onderwijs een multicultureel curriculum dient aan te

15 Barry geciteerd in Parekh, 'Barry and the Dangers of Liberalism', in Multiculturalism reconsidered, red. Paul Kelly (Cambridge: Polity Press, 2002, 133-150), 150. 
bieden; en (5) clitoridectomie bij jonge meisjes niet kan worden toegestaan. ${ }^{16}$ Het grote verschil tussen Barry en Parekh is dat multiculturele accommodaties alleen volgens Parekh een zaak van rechtvaardigheid zijn. Barry beschouwt die ingrepen eerder als een noodzakelijk kwaad, iets dat dus alleen omwille van pragmatische redenen moet worden gedoogd (cf. Mendus 2002). ${ }^{17}$

\section{Redelijke accommodatie in de rechtspraak}

De afgelopen decennia werden er heel wat casussen rond religieuze accommodatie op de werkvloer beoordeeld door nationale gerechtshoven (voor een overzicht, zie Alidadi 2012; Bribosia, Rorive \& Waddington 2013). ${ }^{18}$ Een analyse van deze zaken toont dat de betreffende gerechtshoven tot verschillende oordelen kunnen komen, afhankelijk van de context. ${ }^{19}$ Dat landen anders oordelen heeft onder meer te maken met de margin of appreciation die het EHRM toekent aan de verschillende Europese lidstaten om de godsdienstvrijheid op hun eigen (vaak historisch gegroeide en cultureel bepaalde) manier in te vullen. Het EHRM schrijft dus niet voor hoe alle lidstaten in concreto dienen om te gaan met religie op de werkvloer, maar het markeert wel de (uiterste) grenzen waarbinnen het specifieke beleid van de betreffende lidstaten zich dient te houden (zie voetnoot 1). Wanneer we de nationale rechtsspraak bekijken, dan zien we dat het principe van redelijke accommodatie vooral in de Angelsaksische landen juridisch sterk verankerd is. In Europa zijn er daarentegen geen uniforme wettelijke verplichtingen wat betreft redelijke accommodatie op basis van religie en zien we dat vaak de difference-blind benadering wordt toegepast. Zo oordeelde het EHRM in de casus Dahlab v. Switzerland (EHRM 42393/98, 15 februari 2001) dat scholen mogen eisen dat leerkrachten geen hoofddoek dragen. Ook voor leerlingen en studenten geldt overigens dat er niet noodzakelijk sprake is van een illegitieme inperking van de godsdienstvrijheid wanneer ze verplicht worden hun hoofddoek af te zetten (Leyla Sahin v. Turkey, EHRM 44774/98, 10 november 2005; Dogru and Kervançi v. France, EHRM 27058/05 en 31645/04, 4 december 2008).

Dit betekent echter niet dat het principe van redelijke accommodatie niet zou kunnen worden toegepast op Europees niveau. Zo zou men zowel op grond van artikel 9 (vrijheid van mening, geweten en religie) als van artikel 14 (non-discriminatie) van het EVRM religieuze accommodatie in bepaalde contexten kunnen toelaten. Daarnaast speelt ook Richtlijn 2000/78/EG van de Raad van 27 november 2000 tot instelling van een algemeen kader voor gelijke behandeling in arbeid en beroep (Employment Equality Framework Directive) een fundamentele rol in het

16 Parekh, Barry and the Dangers of Liberalism, 147-149.

17 Susan Mendus. 'Choice, Chance and Multiculturalism', in Multiculturalism Reconsidered, 31-44.

18 Katayoun Alidadi. 'Reasonable Accommodations for Religion and Belief: Adding Value to Article 9 ECHR and the European Union's Anti-Discrimination Approach to Employment?', European Law Review 37/6 (2012): 693-715. Emmanuella Bribosia , Isabelle Rorive en Lisa Waddington, Reasonable Accommodation Beyond Disability in Europe?, European Commission, 2013.

19 Joyce Marie Mushaben. 'Separate and Unequal: Judicial Culture, Employment Qualifications and Muslim Headscarf Debates', Laws 2/3 (2013): 314-336. 
Europese arbeidsrecht, in het bijzonder wat betreft de toepassing en reikwijdte van de hierboven genoemde artikels. Volgens deze richtlijn is er sprake van 'indirecte discriminatie' (art.2, b) indien een schijnbaar neutrale voorziening, regelgeving of praktijk, personen met een bepaalde levensbeschouwing of geloofsovertuiging, beperking, leeftijd of seksuele overtuiging, zou benadelen in vergelijking met andere personen. Echter, wanneer deze voorziening, regelgeving of praktijk op objectieve gronden gebaseerd is en een legitiem doel heeft, kan deze vorm van indirecte discriminatie in bepaalde contexten worden toegelaten. Conform het proportionaliteitsbeginsel kan het verbod op indirecte discriminatie door de gerechtshoven dus zo geïnterpreteerd worden dat redelijke accommodatie van religieuze praktijken legitiem is, maar dit hoeft dus niet noodzakelijk zo te zijn.

Hieronder verduidelijken en concretiseren we een en ander aan de hand van een aantal Europese case studies. We maken hierbij een onderscheid tussen rechtspraak van het HvJ-EU enerzijds en het EHRM anderzijds. Binnen de rechtspraak van het EHRM maken we een verdere opdeling tussen 'neutrale' ondernemingen (deze kunnen privaat, semi-privaat of openbaar zijn) en 'niet neutrale' tendensondernemingen.

\section{Rechtspraak EvJ-EU}

Op 14 maart 2017 heeft het Europees Hof van Justitie zich over twee gerelateerde casussen over private ondernemingen uitgesproken. In de beide casussen (Bougnaoui \& ADDH v. Micropole SA en Achbita \& Centrum voor gelijkheid van kansen en voor racismebestrijding $v$. G4S Secure Solutions NV) ging het erover of religieuze symbolen zijn toegestaan op de werkvloer. Wanneer het HvJ-EU om prejudicieel advies werd gevraagd, kwamen de betreffende Advocaten-Generaal (respectievelijk Eleanor Sharpston en Juliane Kokott) tot uiteenlopende conclusies. $\mathrm{Na}$ een korte bespreking van beide casussen, evalueren we de finale uitspraak van het EvJ-EU.

\subsection{Bougnaoui \& ADDH v. Micropole SA (ECLI:EU:C:2017:204)}

Op 15 juli 2008 startte mevrouw Asma Bougnaoui als projectingenieur bij het Franse IT bedrijf Micropole SA. Na een klacht van een klant die zich 'oncomfortabel' voelde bij het zien van de hoofddoek die Bougnaoui droeg, vroeg de werkgever of mevrouw Bougnaoui bij een volgende contact met de betreffende klant haar hoofddoek zou willen afzetten. Omdat zij dit weigerde, werd ze ontslagen. De casus bereikte het Franse Hof van Cassatie dat vervolgens aan het HvJ-EU de vraag stelde of de eis om de hoofddoek af te zetten al dan niet valt onder de hierboven reeds genoemde Europese richtlijn 2000/78/EG die discriminatie van werknemers op basis van religie of geloofsovertuiging verbiedt. Volgens Advocaat-General Eleanor Sharpston valt de persoonlijke vrijheid om de eigen religie te veruitwendigen inderdaad binnen de reikwijdte van deze richtlijn en werd mevrouw Bougnaoui door haar werkgever benadeeld in vergelijking met werknemers met een gelijkaardige functie die de hoofddoek niet dragen. Volgens 
Sharpston was er in de betreffende casus dus sprake van directe discriminatie op basis van religie of geloofsovertuiging.

\subsection{Achbita \& Centrum voor gelijkheid van kansen en voor racismebestrijding v. G4S}

Secure Solutions NV (ECLI:EU:C:2017:203)

Mevrouw Samira Achbita was sinds 12 februari 2003 tewerkgesteld als receptioniste voor het security bedrijf G4S. In april 2006 deelde Achbita aan haar oversten mee dat ze besloten had de hoofddoek op het werk te dragen, waarop zij het antwoord kreeg dat dit niet zou worden getolereerd omdat het zichtbaar dragen van politieke, filosofische of religieuze tekens indruist tegen de neutraliteit waaraan de onderneming zich hield (ECLI:EU:C:2017:203, §13). Twee maanden later (op 13 juni 2006) werd het arbeidsreglement gewijzigd en werd er duidelijk vermeld dat it is not allowed for employees in the workplace to wear visible signs displaying their political, philosophical or religious convictions, or to manifest related rituals'. Omdat Achbita nog steeds weigerde haar hoofddoek af te zetten, werd ze ontslagen. Begeleid door het Centrum voor gelijkheid van kansen en voor racismebestrijding stapte ze naar het Arbeidshof, dat oordeelde dat er geen sprake was van discriminatie. Vervolgens belandde de casus bij het Hof van Cassatie, dat het HvJ-EU via een prejudiciële vraag om advies vroeg. Dit keer oordeelde Advocaat-Generaal Juliane Kokott dat de richtlijn omtrent discriminatie op de werkvloer niet geschonden was. Volgens Kokott mag een bedrijf immers, onder een aantal voorwaarden, bepaalde restricties op het gebied van religieuze veruitwendiging opleggen aan haar werknemers. Een eerste voorwaarde is dat de regelgeving duidelijk en neutraal geformuleerd is - er mag met andere woorden geen particuliere religie of levensbeschouwing worden geviseerd. Daarnaast is de 'neutrale' profilering van een bedrijf een legitiem doel, ook al kan dit leiden tot een inperking van de godsdienstvrijheid van de werknemers. Tot slot benadrukte Kokott dat de vrijheid van ondernemen bepaalde kledijvoorschriften toelaat, in het bijzonder bij direct klantencontact. Kokott argumenteerde dus dat er in het geval Achbita geen sprake was van discriminatie op basis van religie of geloofsovertuiging en dat het betreffende beleid bijgevolg in overeenstemming was met richtlijn 2000/78/EG.

Wat moest er nu gebeuren met de hierboven geschetste uiteenlopende argumentaties en oordelen? Op 14 maart 2017 werd de gordiaanse knoop door het HvJEU doorgehakt. Het Hof concludeerde dat private werkgevers in de EU hun werknemers mogen ontslaan op basis van het niet-naleven van bepaalde kledingvoorschriften, maar dan wel onder een aantal voorwaarden: (1) de kledingvoorschriften maken deel uit van een coherent en systematisch beleid; (2) de voorschriften zijn enkel van toepassing op werknemers die direct contact met klanten hebben; en (3) de werkgever moet eerst nagaan of de betreffende werknemer niet kan worden overgeplaatst naar een andere functie, vooraleer hij of zij ontslagen wordt. De difference-blind benadering haalt hier dus de bovenhand. Anders dan bijvoorbeeld bij gender, etniciteit, seksuele geaardheid, leeftijd of huidskleur het geval is, wordt iemands religie of levensbeschouwing niet als absoluut gezien en is het, logischerwijze, volgens het HvJ-EU niet onrechtvaardig om op de werkvloer de veruitwendiging van religie in te perken of te verbieden in plaats van te accom- 
moderen. Deze beslissing heeft mogelijks verstrekkende gevolgen. Immers, werkgevers die zich 'neutraal' willen profileren teneinde zich op die manier te conformeren aan het vaak negatieve beeld dat wordt opgezet over religie en in het bijzonder over de islam, zullen dit dus voortaan (mits voldaan aan een aantal voorwaarden) kunnen. Waar religieuze tekens voorheen al konden worden verboden op basis van praktische overwegingen zoals hygiëne en veiligheid (zie hieronder de casus van Chaplin), kunnen werkgevers nu dus ook een veeleer ideologisch' argument van (levensbeschouwelijke) neutraliteit inroepen.

\section{Rechtspraak EHRM}

Niet alleen het HvJ-EU, maar ook het EHRM heeft zich in een aantal casussen uitgesproken over het dragen van levensbeschouwelijke symbolen op de werkvloer. We behandelen achtereenvolgens de casussen Eweida v. UK (EHRM 48420/10) en Chaplin v. UK (EHRM 59842/10) waarover het EHRM zich op 12 april 2011 heeft uitgesproken. Vervolgens gaan we in op Obst v. Germany (EHRM 425/03) en Schüth v. Germany (EHRM 1620/03) die eveneens parallel werden behandeld door het EHRM (op 23 september 2010). Waar de eerste twee casussen betrekking hebben op een 'neutrale' arbeidscontext, verwijzen de twee andere casussen naar identiteitsgebonden organisaties of tendensondernemingen.

\subsection{Levensbeschouwelijk neutrale organisaties: Eweida en Chaplin}

Mevrouw Eweida was tewerkgesteld bij de luchtvaartmaatschappij British Airways (een naamloze vennootschap). In 2004 werd de dresscode voor het personeel gewijzigd en mochten religieuze kledij en/of accessoires niet langer zichtbaar zijn. Wel werden er uitzonderingen voorzien voor sikhs die hun tulband en kara (ijzeren armband) mochten blijven dragen. Ook moslima's werd toegestaan een hoofddoek in de kleuren van het British Airways uniform te dragen. Voor mevrouw Eweida, die een zichtbare halsketting met crucifix droeg, werd echter geen uitzondering gemaakt. De zaak belandde bij het EHRM, dat oordeelde dat er door British Airways geen faire balans was gemaakt tussen enerzijds de nieuwe kledingvoorschriften en anderzijds de gevolgen voor mevrouw Eweida (inperking van de godsdienstvrijheid). Hoewel werkgevers gegronde redenen kunnen hebben om werknemers een bepaald uniform te laten dragen (bv. herkenbaarheid en veiligheid), beschouwde het Hof Eweida's crucifix als een discreet symbool dat geen impact had op Eiwada's professionaliteit, noch op het imago van British Airways. Het EHRM concludeerde bijgevolg

... that, in these circumstances where there is no evidence of any real encroachment on the interests of others, the domestic authorities failed sufficiently to protect the first applicant's right to manifest her religion, in breach of the positive obligation under Article 9 (§95). 
De casus van mevrouw Chaplin is vergelijkbaar en wordt dan ook gewoonlijk in een adem genoemd met die van Eweida. De reden waarom ze in duo worden vermeld, heeft vooral te maken met het feit dat het Hof een andere uitkomst dicteerde. Mevrouw Chaplin was als verpleegster tewerkgesteld in een openbaar ziekenhuis (the Royal Devon and Exeter NHS Foundation Trust)en mocht, ten gevolge van een nieuwe dresscode, haar halsketting met kruisteken niet meer dragen. ${ }^{20}$ Volgens de nieuwe richtlijnen diende het dragen van juwelen tot het absolute minimum beperkt te worden om het gevaar op infectie te reduceren. Net zoals de casus Eweida belandde de casus Chaplin bij het EHRM, maar het Hof kwam tot een andere conclusie, waarbij werd geargumenteerd dat 'the protection of health and safety on a hospital ward, was inherently of a greater magnitude than that which applied in respect of Ms Eweida' (§99) en dat 'the interference with her freedom to manifest her religion was necessary in a democratic society and that there was no violation of Article 9 in respect of the second applicant (\$100)'.

Beide casussen tonen niet enkel aan dat bepaalde rechten en vrijheden kunnen botsen, maar ook aan dat op het eerste zicht vergelijkbare casussen tot verschillende uitkomsten kunnen leiden. Afhankelijk van de context blijkt accommodatie van religieuze (kleding)voorschriften nu eens redelijk, dan weer onredelijk. ${ }^{21}$

\subsection{Tendensondernemingen}

Bovenstaande casussen situeren zich allemaal in een levensbeschouwelijk neutrale context: de betreffende werkgevers zijn niet rechtstreeks geënt op een bepaalde levensbeschouwing of religie. Er bestaan echter ook heel wat non-profitorganisaties en in mindere mate ook profit organisaties, met een religieuze grondslag. Een van de meest gekende voorbeelden van deze laatste categorie is de Amerikaanse winkelketen Hobby Lobby: een hobby- en ambachtenwinkel met een christelijke achtergrond en missie. Deze religieuze achtergrond laat toe dat de winkelketen onder meer bepaalde religie gerelateerde voorwaarden aan haar per-

20 Het openbare ziekenhuis is dus geen private instelling, maar wel een instelling die neutraal is (anders dan het geval is met de tendensondernemingen die we in de volgende paragraaf bespreken).

21 Opmerkelijk is dat in het geval Chaplin - dat dus niet gaat over een private, maar publieke instelling - de onredelijkheid van de accommodatie niet werd gestaafd door de verwijzing naar gebrek aan neutraliteit van een verpleegster met crucifix, maar wel door de criteria 'hygiëne' en 'veiligheid van de patiënten'. Dit betekent - althans dat is onze lezing - dat het Hof hiermee ook onrechtstreeks oordeelt dat religieuze symbolen niet per definitie de neutraliteit van de overheidsinstelling in het gedrang brengen. 
soneel mag opleggen. ${ }^{22}$ Ook volgens de Raad van Europa is dat mogelijk, zoals te lezen is in de reeds vermelde richtlijn 2000/78/EG:

EU richtlijn 2000/78/EG, Artikel 4: Wezenlijke beroepsvereisten: ${ }^{23}$

1 Niettegenstaande artikel 2, leden 1 en 2, kunnen de lidstaten bepalen dat een verschil in behandeling dat op een kenmerk in verband met een van de in artikel 1 genoemde gronden berust, geen discriminatie vormt, indien een dergelijk kenmerk, vanwege de aard van de betrokken specifieke beroepsactiviteiten of de context waarin deze worden uitgevoerd, een wezenlijke en bepalende beroepsvereiste vormt, mits het doel legitiem en het vereiste evenredig aan dat doel is.

2 De lidstaten kunnen op het moment van vaststelling van deze richtlijn bestaande nationale wetgeving handhaven of voorzien in toekomstige wetgeving waarin op de datum van vaststelling van deze richtlijn bestaande nationale praktijken worden opgenomen, die bepaalt, dat in het geval van kerken en andere publieke of particuliere organisaties, waarvan de grondslag op godsdienst of overtuiging is gebaseerd, voor wat betreft de beroepsactiviteiten van deze organisaties een verschil in behandeling gebaseerd op godsdienst of overtuiging van een persoon geen discriminatie vormt indien vanwege de aard van de activiteiten of de context waarin deze worden uitgeoefend de godsdienst of overtuiging een wezenlijke, legitieme en gerechtvaardigde beroepsvereiste vormt gezien de grondslag van de organisatie. Dit verschil in behandeling wordt toegepast met inachtneming van de grondwettelijke bepalingen en beginselen van de lidstaten en van de algemene beginselen van het Gemeenschapsrecht, en mag geen op een andere grond gebaseerde discriminatie rechtvaardigen.

3 Mits de bepalingen van deze richtlijn voor het overige worden geëerbiedigd, laat deze richtlijn derhalve het recht van kerken en andere publieke of particuliere organisaties waarvan de grondslag op godsdienst of overtuiging is gebaseerd, onverlet om, handelend in overeenstemming met de nationale grondwettelijke en wettelijke bepalingen, van personen die voor hen werk-

22 In de casus Burwell v. Hobby Lobby (573 U.S) oordeelde het Amerikaanse Hoger Gerechtshof op 30 juni 2014 dat werkgevers kunnen weigeren om bepaalde ziektekosten van hun personeelsleden terug te betalen, als de behandeling in kwestie indruist tegen hun religie. Conform een destijds nieuwe wetgeving (de zogenaamde 'Obamacare') moesten werkgevers immers een ziekteverzekering voor hun werknemers voorzien, die onder meer anticonceptiva terugbetaalt. Omdat het gebruik van anticonceptiva indruist tegen de (christelijke) geloofsovertuiging van de uitbaters van de Hobby Lobby-keten, voelden zij zich geschonden in hun godsdienstvrijheid. De zaak kwam terecht bij het Amerikaans Hoger Gerechtshof dat de werkgever met een nipte 5-4 meerderheid in het gelijk heeft gesteld.

23 Zie in dit verband ook $\$ 23$ van de betreffende richtlijn: 'In een zeer beperkt aantal omstandigheden kan een verschil in behandeling gerechtvaardigd zijn wanneer een met godsdienst of overtuiging, handicap, leeftijd of seksuele geaardheid verband houdend kenmerk een wezenlijke en bepalende beroepsvereiste vormt, mits het doel legitiem is en het vereiste daaraan evenredig is; in de informatie die de lidstaten aan de Commissie verstrekken, moet aangegeven worden welke omstandigheden het betreft.' 
zaam zijn, een houding van goede trouw en loyaliteit aan de grondslag van de organisatie te verlangen.

De vraag is echter hoe ver werkgevers kunnen gaan in hun 'religieuze' vereisten voor werknemers, zonder daarbij een aantal fundamentele rechten en vrijheden van deze werknemers, zoals de vrijheid van mening, expressie, en religie alsook het recht op privacy en non-discriminatie te schenden. Mogen katholieke, protestantse, joodse en islamitische scholen leerkrachten ontslaan omwille van hun seksuele geaardheid of huwelijksstatus? Is het legitiem om als christelijke school bij de personeelsaanwerving voorrang te geven aan gedoopte leerkrachten? Is het legitiem om personeel in katholieke ziekenhuizen te ontslaan omdat ze de kerkelijke leer inzake het levenseinde openlijk bekritiseren?

Anders dan in de voorgaande casussen is de vraag hier niet in hoeverre werknemers hun religie kunnen en mogen manifesteren in een seculiere of neutrale arbeidsomgeving (positieve godsdienstvrijheid), maar gaat het erom of, en hoe, werknemers in een religieus geïnspireerde arbeidscontext beschermd kunnen en moeten worden tegen de levensbeschouwelijke vereisten van de werkgever (negatieve godsdienstvrijheid).

Opnieuw botsen er een aantal rechten en vrijheden en komt het erop aan een faire balans te vinden tussen rechten en plichten van werkgevers enerzijds en van werknemers anderzijds. Het EHRM heeft alvast in een aantal zaken een poging ondernomen om de krijtlijnen van de godsdienstvrijheid af te bakenen waar deze botst met andere rechten en vrijheden. We bespreken kort twee vergelijkbare casussen: Obst v. Germany en Schüth v. Germany. Beide casussen gaan over werknemers van een tendensonderneming die werden ontslagen omwille van hun huwelijksstatus. Obst (een organist/koorleider in een katholieke parochie) en Schüth (PR-manager van de mormoonse kerk) zijn op het moment dat ze in dienst waren voor de betreffende werkgever gescheiden van hun echtgenotes en zijn een relatie aangegaan met een nieuwe partner. Voor de betreffende werkgevers was deze privékwestie een gegronde reden om over te gaan tot een ontslag. In de casus van Schüth kwam daar nog bij dat zijn nieuwe partner een kind van hem verwachtte, wat maakt dat hij niet enkel beschuldigd werd van overspel, maar ook van bigamie. Beide casussen bereikten het Duitse Grondwettelijk Hof dat argumenteerde dat de geloofwaardigheid van de betreffende geloofsgemeenschappen/kerken niet langer gegarandeerd was indien Obst en Schüth er aan het werk zouden blijven. In 2003 belandden de casussen bij het EHRM dat deels tot een ander oordeel kwam: terwijl het ontslag van Schüth volgens het Hof redelijk en proportioneel was, was dat niet het geval voor Obst.

In de beoordeling van deze casussen heeft het EHRM rekening gehouden met een aantal factoren, die ook in vergelijkbare casussen (bv. Rommelfanger v. Germany, EHRM 12242/86, 6 September 1989; Siebenhaar v. Germany, EHRM 18136/02, 3 februari 2011; en Fernandez Martinez v. Spain, EHRM 56030/07, 12 juni 2014) een rol speelden. Vooreerst is er de functie van de aanklager: als PR-manager in de mormoonse kerk had Schüth een grotere verantwoordelijkheid dan Obst die organist en koorleider was in een katholieke parochie. Ten tweede is er de aard van de 
overtreding: in welke mate zijn overspel en bigamie 'aanstootgevend' (offensive) en gaan ze in tegen het principe van de loyaliteit ten aanzien van de werkgever? Zowel bij Obst als bij Schüth waren hun 'aanstootgevende activiteiten' niet expliciet verbonden met hun arbeidsfunctie, maar dat is natuurlijk niet altijd zo. Zo oordeelde het EHRM in een andere Duitse casus (Rommelfanger v. Germany), waarin een arts in een katholiek ziekenhuis de katholieke leer inzake abortus openlijk bekritiseerde, dat deze 'overtreding' inderdaad niet door de beugel kon, waarbij onder meer werd verwezen naar de functie die Rommelfanger uitoefende. Tot slot wordt ook rekening gehouden met de gevolgen van een mogelijk ontslag. Zo kon Schüth als PR-manager makkelijk een nieuwe baan vinden, wat minder vanzelfsprekend was voor Obst. Ook dit was een van de redenen waarom het EHRM de inperking van artikel 8 EVRM (recht op privacy) in het geval van Schüth redelijk en proportioneel achtte, terwijl het Hof oordeelde dat dit niet het geval was bij Obst.

Beide casussen tonen aan dat de religieuze identiteit van een organisatie of onderneming een bepalende factor kan zijn in het personeelsbeleid. Om de vrijheid van onderneming, vereniging en godsdienst te vrijwaren, kunnen tendensondernemingen bepaalde vormen van loyaliteit eisen van het personeel die niet zijn toegelaten in een 'seculiere' context, al zijn deze eisen niet absoluut, maar contextafhankelijk. Die contextualiteit hangt samen met het feit dat nogal wat gehanteerde concepten in de discussie rond het accommoderen van religie op de werkvloer, voor interpretatie vatbaar zijn. Hieronder gaan we daar dieper op in.

\section{Conceptuele vaagheid: context matters}

Eigen aan de discussies over religie en werk is dat er voortdurend wordt gewerkt met een arsenaal aan concepten zoals 'neutraliteit', 'religie', 'redelijkheid', 'haalbaarheid', 'proportionaliteit', 'onbillijke gevolgen' en 'discriminatie', die uitnodigen tot interpretatie en precies daarom ook tot uiteenlopende rechtsspraak en beleidskeuzes nopen. Hieronder overlopen we kort een aantal van die concepten. We tonen aan waarin precies de ambiguïteit schuilt en op welke manier contextuele analyse soelaas kan bieden.

\subsection{Neutraliteit}

Het concept 'neutraliteit', dat zowel door voor- als tegenstanders van redelijke accommodatie van religie wordt gebruikt, is vaag en onduidelijk. Zo menen verdedigers van de difference-sensitive benadering dat gelijkheid in de praktijk enkel gegarandeerd kan worden wanneer er rekening wordt gehouden met verschillen. Die focus op verschil kan er dan weer toe leiden dat mensen op basis van cultuur/ religie anders worden behandeld - iets wat niet altijd als 'neutraal' wordt beschouwd door voorstanders van de difference-blind benadering. Volgens deze benadering moet ongelijke behandeling op basis van religie immers vermeden worden omdat dit net leidt tot ongelijkheid en bijgevolg kan omslaan in het 
tegendeel van de beoogde 'neutraliteit'. Veel hangt dus af van hoe men cultuur en religie ontologisch duidt: als een onafscheidbaar en dus wezenlijk element van iemands persoon of als een onderdeel van een persoon waarover men te allen tijde verantwoordelijk blijft.

\subsection{Religie}

Als men beslist rekening te houden met religieuze claims als basis voor uitzonderingsrechten (en dus de difference sensitive approach volgt), dan is een probleem waarmee men snel wordt geconfronteerd de onduidelijkheid over wat 'religie' nu precies is. 'Religie' is een ambigu concept, wat onder meer blijkt uit de recente studie van zogenaamde 'pseudo-religies', 'parodie-religies', 'hyper-religies' en 'uitgevonden religies'. ${ }^{24}$ Het bekomen van een universele en tijdloze definitie van 'religie' wordt verder ook bemoeilijkt door de individualisering, de-institutionalisering en dynamiek van religie. Bijgevolg is het niet altijd duidelijk waarover het precies gaat wanneer we het hebben over 'godsdienstvrijheid' en over de redelijke accommodatie van 'religie'. Om duidelijk af te bakenen wat onder 'religie' verstaan wordt, zonder daarbij het principe van overheidsneutraliteit en de daarmee gepaard gaande scheiding tussen kerk en staat aan te tasten, zou de wetgever rekening kunnen houden met datgene wat burgers als 'religieus' omschrijven. In dat geval bestaat echter het gevaar dat er heel wat onder de noemer 'religie' kan vallen. Eén van de bekendste voorbeelden is de kerk van het vliegend spaghettimonster of het pastafarianisme. Hoewel deze 'kerk' vooral een persiflage op 'religie' is, worden door deze 'kerk' voltrokken huwelijken erkend in Nieuw-Zeeland, en mogen haar leden onder meer in Oostenrijk, Tsjechië, Rusland, Utah en Texas met een pastavergiet op de foto van officiële documenten zoals een rijbewijs. Anderzijds werd de poging van de betreffende 'kerk' om als religie erkend te worden in de Amerikaanse staat Nebraska in 2016 in de kiem gesmoord, waarbij de rechter oordeelde dat pastafarianisme geen religie is, maar 'rather, a parody, intended to advance an argument about science, the evolution of life, and the place of religion in public education' (Cavanaugh v. Bartelt, 4:14-CV-3183, D. Neb., 28 april 2016) Op een vergelijkbare manier oordeelde ook de Nederlandse Raad van State op 15 augustus 2018 dat het pastafarianisme geen religie is (ECLI:NL:RVS:2018:2715).

Om 'gefingeerde' religies te vermijden, zou men het niet aan burgers kunnen overlaten om te bepalen wat religie is, maar aan de overheid of de rechtbank. In dat geval bestaat echter het gevaar dat traditionele en geïnstitutionaliseerde religies bevoorrecht worden, terwijl minder traditionele en meer geïndividualiseerde religies uit de boot vallen (cf. Sullivan 2004; Hurd 2007). ${ }^{25}$ Dat werpt dan weer vraagtekens op inzake de neutraliteit van de overheid en de scheiding tussen kerk

24 Christine Cusack. Invented religions: Imaginations, fiction and faith (Farnam, Burlington: Ashgate Publishing, 2010). Adam Possamai. Handbook of hyper-real religions (Leiden, New York: Brill, 2012).

25 Elisabeth Shakman Hurd. Beyond religious freedom. The new global politics of religion (Princeton: Princeton University Press, 2015). Winnifred Sullivan. The impossibility of religious freedom (Princeton: Princeton University Press, 2004). 
en staat. Volgens het principe van interpretatieve terughoudendheid komt het immers niet toe aan de rechter om te bepalen welke opvattingen en/of handelingen al dan niet 'religieus' zijn, want dat zou onvermijdelijk leiden tot een schending van de overheidsneutraliteit.

Omwille van de conceptuele vaagheid inzake 'religie' en de (juridische) moeilijkheden die dat met zich meebrengt, pleiten sommigen er voor om het recht op godsdienstvrijheid af te schaffen. Dit pleidooi gaat doorgaans gepaard met een pleidooi voor een meer 'inclusieve' benadering, waarbij 'religie' niet langer wordt opgevat als een aparte, 'bijzondere' categorie, maar religieuze en seculiere levensovertuigingen op gelijke voet worden behandeld. ${ }^{26}$ Zo stelt Swan ${ }^{27}$ dat 'religion isn't special; rather, it should be viewed as legally on an equal basis with other sectarian commitments, including secular ones'. Eerder dan te werken met religie als een aparte rechtscategorie waarvoor er dan redelijke accommodaties kunnen worden gevraagd, zou het moeten gaan over 'constitutieve bindingen' - bindingen die gekoppeld zijn aan iemands morele en psychologische integriteit en die raken aan iemands existentiële kern:

[...] [B]eliefs that engage my conscience and the values with which I most identify, and those that allow me to find my way in a plural moral space, must be distinguished from my desires, taste, and other personal preferences, that is, from all things liable to contribute to my well-being but which I could forgo without feeling as if I were betraying myself or straying from the path I have chosen. The nonfulfillment of a desire may upset me, but it generally does not impinge on the bedrock values and beliefs that define me in the most fundamental way; it does not inflict "moral harm". ${ }^{28}$

Deze verbreding leidt echter tot nieuwe problemen waarvan we er hier, op een drafje, een aantal oplijsten. Vergelijkbaar met het definitieprobleem van religie kan men zich onder meer de vraag stellen wat nu precies een 'constitutieve' binding is. Ook de vraag hoe iemand kan 'bewijzen' dat de gewenste claim samenhangt met zijn of haar integriteit is allesbehalve evident. In het verlengde van die

Christopher Eisgruber, en Lawrence Sager, Religious freedom and the constitution (Cambridge: Harvard University Press, 2007). Kent Greenawalt Religion and the constitution. Volume 1-2 (Princeton: Princeton University Press, 2009). Hurd, Beyond religious freedom. Cécile Laborde, 'Conclusion: is Religion Special?, in Religion, Secularism \& Constitutional Democracy, red. Jean Cohen en Cécile Laborde (New York: Columbia University Press, 2016), 423-433. François Levrau, , 'Voorbij de Godsdienstvrijheid?', Ethische Perspectieven, 28/1 (2018a): 23-36. François Levrau, 'Pluriform Accommodation. Justice Beyond Multiculturalism and Freedom of Religion', Res Philosophica, 95/1 (2018b): 85-112. Jocelyn Maclure , 'Conscience, Religion, and Exemptions: An Egalitarian View', in Religious exemptions, red. Kevin Vallier en Michael Weber (Oxford: Oxford University Press, 2018), 9-20. Michael Perry, , 'On the Constitutionality and Political Morality of Granting Conscience-Protecting Exemptions only to Religious Believers', in Religious exemptions, 21-36. Sullivan, The impossibility of religious freedom. Kyle Swan, , 'How Should we Treat Religion? On Exemptions and Exclusion', in Religious exemptions, 37-58.

27 Swan, How should we treat religion?, 58.

28 Jocelyn Maclure en Charles Taylor, Secularism and freedom of conscience (Cambridge: Harvard University Press, 2011), 77. 
vraag rijzen er mogelijks ook problemen met iemands privacy die in het gedrang komt wanneer van hem/haar wordt gevraagd te 'bewijzen' dat de claim authentiek is. Ook leidt de mogelijkheid om constitutieve bindingen te accommoderen tot de vraag wat nu precies 'redelijke' accommodaties zijn (zie infra). Heeft men door te werken met 'constitutieve bindingen' niet de spreekwoordelijke doos van Pandora geopend waarbij iedereen claims kan formuleren omdat heel wat mensen (en dus niet enkel gelovigen) aan 'iets' gebonden zijn - denk aan levensstijlen, subculturen en allerhande overtuigingen zoals vegetarisme (een binding die thans al vaak wordt erkend), maar ook aan naturisme, gothic, diepe liefde voor een voetbalclub, 'pink as a lifestyle', etc.? De kans dat hier misbruik van wordt gemaakt is reëel, maar mogelijk misbruik is er ook wanneer men religie als aparte rechtsgrond wil behouden. Bekend is niet alleen het pastafarianisme, maar bijvoorbeeld ook de Gentse 'Rokerskerk' waarin caféhouders die het niet eens waren met een rookverbod zich verenigd hadden en hun zaak 'omdoopten' tot een kerk, teneinde onder het mom van godsdienstvrijheid klanten toe te staan te roken. ${ }^{29}$ In Nederland is er de 'Kloosterorde van de Zusters van Sint Walburg' die het aanbieden van seksshows als een onderdeel van de godsdienstuitoefening zag. ${ }^{30}$ Ook de Santo Daimekerk waarvan de leden in de eredienst de hallucinerende ayauasca thee gebruiken is berucht. ${ }^{31}$ Deze en andere 'gefingeerde religies' lijken een bepaald voordeel te willen halen uit het recht op godsdienstvrijheid en uit het feit dat het begrip religie moeilijk te definiëren is. ${ }^{32}$

\subsection{Redelijkheid en proportionaliteit}

Beslist men dat religies en/of constitutieve bindingen mogen worden geaccommodeerd, dan is het de vraag hoe ver men daar in kan en mag gaan. Accommodatie van religie dient immers 'redelijk' (reasonable) te zijn, maar wat houdt dat precies in? Is het toelaten van bij wet verboden hallucinogene middelen in een religieuze context 'redelijk', of is het onredelijk om een illegaal middel in een bepaalde - in casu religieuze - context plots wel als legaal te beschouwen? Wat met levensbeschouwelijke praktijken en veruitwendigingen op de werkvloer? Is

29 Corr. Gent 30 oktober 2012, onuitgegeven. Zie ook Jogchum Vrielink, 'Gentse Rechtbank Gelooft Niet In Rokerskerk', De Juristenkrant, 258(2012): 1-2.

30 HR 31 oktober 1986, NJ 1987/173 (Zusters van Sint Walburga). Het Hof en de Hoge Raad oordeelden dat Sint Walburga geen zelfstandig kerkgenootschap is en dat hun gebouw geen lokaal is dat is bestemd voor godsdienst. Ook de seksshows werden niet beschouwd als godsdienstuitoefening.

31 Deze casus bereikte in 2007 het EHRM, dat oordeelde dat het rituele gebruik van de betreffende thee onder art. 9 EVRM valt, maar dat de inperking van dit recht (middels het verbod op de thee, die valt onder de lijst van de Nederlandse Opiumwet) geen illegitieme inperking vormt van art. 9 en art. 14 EVRM (EHRM, Alida Maria Fränklin-Beentes and Ceflu-Luz da Floresta v. the Netherlands, 28167/07, 4 juli 2007). Zie hierover ook Broeksteeg, Hansko, 'Over Hallucinerende Thee en de Vrijheid van Godsdienst', Actioma 30 januari 2015, online toegankelijk via http://actioma.eu/ 2015/01/over-hallucinerende-thee-en-de-vrijheid-van-godsdienst (laatst bezocht op 19 februari 2020).

32 Levrau, Voorbij de Godsdienstvrijheid. Jogchum Vrielink, 'Religie Tussen Definitie en Divinatie. Over de Rokerskerk, Satanische Zusters en Onzichtbare Roze Eenhoorns', Nieuw Juridisch Weekblad, 278(2013): 190-198. 
het redelijk om van ambtenaren te eisen dat ze hun levensbeschouwelijke tekens thuislaten omdat ze anders de schijn van partijdigheid wekken? Of is het net redelijk om als overheid een inclusief en representatief beleid te voeren en ambtenaren tewerk te stellen die zich religieus uiten? Is het redelijk om sikhs een uitzondering te geven inzake het niet dragen van een helm op een bouwwerf teneinde hun sociaaleconomische kansen niet te beperken of is dit veeleer een voorbeeld van 'een onverzettelijke minderheid' die bevoorrecht wordt? En als het 'redelijk' is om een hoofddoek toe te staan op de werkvloer moet dan ook een pet als vestimentair attribuut van een urban subculture worden toegelaten? Waar trekt men precies de grens? Hoe ver reikt de redelijkheid precies? Wie moet hierover oordelen en op basis van welke criteria? Deze vraag over de redelijkheid is verwant met de vraag wat 'onredelijke' kosten zijn voor een werkgever wanneer deze zijn werkomgeving dient aan te passen aan personeel met een fysieke beperking (bv. lift, sanitaire aanpassingen, etc.). Ook daarover valt moeilijk eenduidig een antwoord te geven omdat veel afhangt van wat er precies wordt gevraagd en in welke context dat gebeurt. Deze vraag over 'redelijkheid' leunt dus dicht aan bij de vraag wat 'haalbaar' is.

Deze redelijkheid vergt een afweging, oftewel een proportionaliteitstoets, die soms in het voordeel van de accommodatie, en soms in het nadeel van de accommodatie zal wijzen. Zo oordeelde het EHRM dat een ketting met een kruisteken een discreet symbool is, terwijl een hoofddoek niet als (even) discreet wordt opgevat. Op haar beurt kan een hoofddoek dan weer anders worden gepercipieerd dan een boerka, zeker wanneer werkgevers direct klantencontact hebben. ${ }^{33} \mathrm{Op}$ een analoge manier kan het accommoderen van religieuze gebedsmomenten tijdens de werkuren geweigerd worden in een functie waarbij personeelsleden stand-by moeten zijn, terwijl het accommoderen van bijvoorbeeld de hoofddoek in diezelfde functie misschien wel zou kunnen. En terwijl het openlijk uiten van kritiek op het katholieke abortusbeleid in de casus Rommelfanger als aanstootgevend werd beschouwd, is het niet zeker dat het hebben van een buitenechtelijke relatie in dezelfde context evenzeer als aanstootgevend zou worden opgevat.

De redelijkheid van de accommodatie zal ook steeds geval per geval moeten worden bepaald, waarbij de impact die de accommodatie (of het gebrek eraan) op verschillende betrokken partijen (collega's, werkgever, werknemer, klanten of patiënten, etc.) moet worden bekeken. Volgens het accommodatie proviso kan een accommodatie bijvoorbeeld redelijk zijn, als de accommodatie van een werknemer niet gepaard gaat met een benadeling van collega's. ${ }^{34}$ Ook de benadeling voor de werkgever moet bekeken worden. Wanneer het gaat over tendensondernemingen

33 Levrau en Loobuyck, With or Without Religious Symbols? Zo is het bijvoorbeeld sinds 2017 in Québec niet langer toegestaan om als ambtenaar een niqab of boerka te dragen bij publieke dienstverlening, terwijl het dragen van de hoofddoek in dat geval wel kan. (Loi favorisant le respect de la neutralité religieuse de l'État et visant notamment à encadrer les demandes d'accommodements pour un motif religieux dans certains organismes, 18 oktober 2017). Ook buiten het arbeidsrecht zien we dat de boerka in toenemende mate als problematisch wordt ervaren en het dragen ervan in bepaalde contexten verboden wordt, terwijl dat niet geldt voor bijvoorbeeld de hoofddoek. 
zien we bijvoorbeeld dat de geloofwaardigheid van deze ondernemingen een belangrijk aandachtspunt is: zo kon de geloofwaardigheid van de katholieke kerk volgens het EHRM niet langer gegarandeerd worden wanneer Fernando Martinez zijn baan als godsdienstleerkracht zou behouden nadat openlijk bekend was dat hij lid was van een vereniging voor het optioneel celibaat. Bovendien zou de godsdienstvrijheid van ouders geschonden kunnen worden als hij in dienst zou blijven omdat ouders kiezen voor 'geloofwaardig' godsdienstonderwijs dat volgens het Hof niet langer gegarandeerd zou zijn. Daarnaast moet er ook rekening worden gehouden met de gevolgen voor de betrokken werknemers, zoals onder meer de zaken Schüth en Obst aantonen. Vanzelfsprekend moet ook de impact op de 'gebruiker' (klant, patiënt, etc.) bekeken worden. Zo had de keuze van Chaplin om een ketting met kruis te dragen volgens het EHRM immers grotere gevolgen dan de keuze van Eweida om een gelijkaardige ketting te dragen.

\subsection{Discriminatie}

Een nauw aan het vorige punt verwante bedenking heeft te maken met de vraag wanneer er wel/geen sprake is van discriminatie. Als algemene regel geldt dat sollicitanten en werknemers met gelijke kwalificaties niet gediscrimineerd mogen worden op basis van religie, geloofsovertuiging, fysieke beperkingen, gender, leeftijd of seksuele geaardheid. In bepaalde gevallen kunnen er echter, zowel door organisaties met als zonder levensbeschouwelijke grondslag, specifieke eisen worden opgelegd die mogelijk als discriminerend door de werknemers kunnen worden gepercipieerd. Zo is het bijvoorbeeld evident dat acteurs voor bepaalde filmrollen gescreend worden op basis van onder meer geslacht, leeftijd en huidskleur, en is het legitiem om als minister enkel kabinetsmedewerkers met een bepaalde politieke voorkeur aan te werven. Zo ook zullen voetbalclubs enkel trainers aanwerven die kennis van voetbal hebben en zal de groendienst enkel mensen rekruteren die over kennis beschikken over planten. ${ }^{35}$ Dit zijn redelijke en noodzakelijke functievereisten die toestaan dat sommige mensen wel en anderen niet in aanmerking komen voor een baan.

Op een vergelijkbare manier kunnen werkgevers met een religieuze grondslag bepaalde eisen opleggen aan hun werknemers (bv. gedoopt zijn, niet gescheiden zijn, etc.), zonder daarbij het recht op non-discriminatie illegitiem in te perken.

Religion-based hiring by a religious organization is rationally related to its nature and purpose. Discrimination only becomes negative when it makes arbitrary, irrational distinctions based on prejudice, as when an entire category of persons (women, African-Americans, Hispanics, those with a handicap) is rejected and held to be unqualified. (Monsma 2012, 80)

Zolang het betreffende beleid te verantwoorden is in het licht van de aard en doelstellingen van de onderneming, kan het 'recht om uit te sluiten' (Monsma 
2012, 74) zowel in seculiere ondernemingen als in tendensondernemingen legitiem zijn. Op het eerste zicht lijkt dit plausibel en evident, maar een diepere analyse toont algauw dat er opnieuw 'conceptuele vaagheid' op de loer ligt. Het is immers niet altijd duidelijk wanneer een bepaalde praktijk een 'wezenlijke, legitieme en gerechtvaardigde beroepsvereiste vormt gezien de grondslag van de organisatie' en dus juridisch gezien onder richtlijn 2000/78/EG valt. Mogen kapsalons bijvoorbeeld weigeren om vrouwen met een hoofddoek aan te werven omdat dit tegen hun 'aard' en 'doelstellingen' ingaat? Een Britse rechtbank oordeelde alvast in de zaak Noah v. Desrosiers (Employment Tribunal Case No. 2201867/07, 29 mei 2008) dat de uitbaatster van een kapsalon religieuze uitingen moet tolereren, ook als die zouden indruisen tegen haar (commerciële) opvatting over hoe dat kapsalon en de kapsters er zouden moeten uitzien. ${ }^{36}$ Zoals hoger geduid heeft het HvJ-EU op 14 maart de deur echter op een kier gezet: werkgevers kunnen via het argument van 'neutraliteit' bekomen dat werknemers hun religieuze en andere tekens thuis laten. Een mogelijk gevolg van deze uitspraak is dat werkgevers onder het mom van neutraliteit (en het bijhorend ideaal van gelijke behandeling) zouden kunnen discrimineren en neutraliteit dus op veeleer slinkse wijze inzetten om zich van religie te distantiëren.

Het antwoord op de vraag of redelijke accommodatie voor religieuze claims moet worden toegestaan, hangt dus in grote mate af van de context. Zo maakte het HvJ-EU in haar beoordeling van de casus Achbita onder meer een onderscheid tussen banen met en zonder direct klantencontact. In de casussen Obst en Schüth wees het EHRM er dan weer op dat Schüth, als PR-verantwoordelijke, een grotere verantwoordelijkheid voor de kerk had dan Obst, wat maakt dat het ontslag van Schüth beter te verantwoorden was dan dat van Obst. Katholieke scholen kunnen dan weer meer loyaliteit vragen van hun godsdienstleerkrachten dan van de leerkrachten van seculiere vakken, terwijl er tegelijkertijd meer loyaliteit kan gevraagd worden van onderwijspersoneel dan van administratief en technisch personeel, dat beduidend minder contact heeft met leerlingen. Op een vergelijkbare manier zal een kerk als werkgever religieuze restricties kunnen opleggen aan een priester, maar geen (of minder) aan de tuinman die de graspleintjes rond de kerk in orde brengt:

(...) [T] here is no problem in a church's discriminating on religious grounds in its appointment of a priest or in a mosque's doing so in its appointment of an baan wilde geven in haar kapsalon. Het hof moest een afweging maken of wat Desrosiers voorstond proportioneel was in het licht van een legitiem doel. Beslist werd dat dit niet het geval was. Desosiers ging er te sterk vanuit dat de hoofddoek nadelig zou zijn voor haar kapsalon. Gezien ze zelf haar haar zou blijven tonen zouden klanten ook wel snel begrijpen dat de hoofddoek een persoonlijke keuze is van Noah en dus niks te maken heeft met het kapsalon. Het tonen van het haar is ten andere ook niet noodzakelijk om de job goed ten uitvoer te brengen. In die zin was er sprake van indirecte discriminatie. 
imam, although there may well be a problem if either takes account of an applicant's faith when it appoints a gardener or a cleaner or an accountant. ${ }^{37}$

\section{Conclusie}

Een vraag die de meningen verdeelt, is of accommodaties voor religie (op de werkvloer) kunnen worden verzoend met de principes van gelijkheid en neutraliteit. Volgens multiculturalisten zoals Bhikhu Parekh is het antwoord duidelijk. Accommodaties zijn een kwestie van meer rechtvaardigheid. Monsma \& Carlson-Thies ${ }^{38}$ stellen bijvoorbeeld dat 'granting exemptions to believers from otherwise valid laws when they clash with their beliefs [...is ] among the best of our traditions' omdat een dergelijk beleid daadwerkelijk rekening houdt met de vrijheid van godsdienst. Bovendien is er niet enkel behoefte aan het accommoderen van religie in de seculiere werkomgeving, maar moeten organisaties met een religieuze grondslag eveneens het recht hebben 'to hire employees who actually support the religious mission and will faithfully execute it ${ }^{39}$ of om werknemers die dat niet doen te weigeren of ontslaan. Brian Barry is een andere mening toegenegen omdat het toekennen van uitzonderingen volgens hem onherroepelijk tot ongelijkheid leidt. Enkel omwille van pragmatische redenen kunnen uitzonderingsregels (tijdelijk en zolang de ongelijkheid aanhoudt) worden gelegitimeerd. De minderheidsrechten die door multiculturalisten worden verdedigd, sluipen op die manier via een achterpoortje ook binnen in Barry's egalitair-liberalisme. Afhankelijk van de filosofische positie die men heeft, kunnen redelijke accommodaties dus worden beschouwd als noodzakelijk vanuit het oogpunt van rechtvaardigheid of als iets dat veeleer voortvloeit uit pragmatische overwegingen.

De vraag blijft echter wanneer en op basis van welke criteria dit soort uitzonderingsrechten kunnen worden toegelaten, in het bijzonder wanneer deze rechten met andere rechten en vrijheden botsen en invloed kunnen hebben op externe partijen. Juridische conflicten over het accommoderen van religie in de arbeidscontext zijn dan ook legio in Europa en naar alle waarschijnlijkheid zal die discussie in de nabije toekomst niet worden beslecht. Door de verschillende interpretaties van het concept 'gelijkheid' (en de daarmee gepaard gaande spanning tussen de difference-blind en de difference-sensitive benadering) en omwille van de onduidelijkheid van een aantal belangrijke concepten lijkt het vinden van een eenduidige uitweg nagenoeg onmogelijk. Uit de in deze bijdrage besproken casuïstiek blijkt dat er inderdaad geen uniform antwoord is op de vraag wanneer religieuze claims moeten worden geaccommodeerd, tenzij dan het antwoord dat de

37 Peter Jones, 'Toleration, Religion and Accommodation', European Journal of Philosophy, 2012, 12-13. http://onlinelibrary.wiley.com/doi/10.1111/j.1468-0378.2012.00549.x/pdf [laatst bezocht op op 11 april 2014].

38 Stephen Monsma en Stanley Carlson-Thies, Free to serve. Protecting the religious freedom of faithbased organizations (Michigan: Brazos Press, 2015), 123.

39 Laylock, geciteerd in Monsma en Carlson-Thies, Free to serve, 20. 
context in grote mate bepalend is voor het gekozen beleid. Andrew Koppelman ${ }^{40}$ stelt dan ook terecht dat

the decision whether to treat religion specially in any particular case requires the decision maker (...) to balance the good of religion against whatever good the generally applicable law seeks to pursue. That balancing is a matter of context-specific judgment. It is not reducible to any legal formula.

Een dergelijke contextuele benadering die in de rechtspraak tot uiting komt via het proportionaliteitsbeginsel ${ }^{41}$ houdt dan rekening met verschillende factoren (bv. functie, arbeidskansen, aard van de 'aanstootgevende' handeling, impact op anderen, nationale/lokale context,...), wat ertoe kan leiden dat casussen die op het eerste zicht gelijkaardig zijn, uiteindelijk toch uiteenlopende uitkomsten met zich meebrengen.

40 Andrew Koppelman, Defending American religious neutrality (Harvard: Harvard University Press, 2013), 164.

41 Jos Vleugel, 'Religie, Belangenafweging en Neutraliteit', Tijdschrift voor Religie, Recht en Beleid 2019 (3): 32-51. 